\title{
DESAFIOS NA IMPLEMENTAÇÃO DO PLANO DIRETOR COMO GARANTIA DE UM MEIO AMBIENTE ECOLOGICAMENTE SUSTENTÁVEL
}

\section{CHALLENGES IN THE IMPLEMENTATION OF THE MASTER PLAN AS A GUARANTEE OF AN ECOLOGICALLY SUSTAINABLE ENVIRONMENT}

\author{
VLADIMIR PASSOS DE FREITAS \\ Professor do Programa de Pós-Graduação em Direito \\ Pontifícia Universidade Católica do Paraná (PUCPR) \\ vladimir.passos@pucpr.br \\ Clayton Santos do Couto \\ Professor dos cursos de graduação e pós-graduação em Direito \\ Pontifícia Universidade Católica do Paraná (PUCPR) \\ clayttoncouto@hotmail.com
}

Fecha de recepción: 1 de abril de 2021 / Fecha de aceptación: 17 de mayo de 2021

RESUMO: O objetivo principal deste estudo é o de analisar os aspectos mais importantes do plano diretor participativo, instrumento para a consecução da ordenação urbana e garantia do direito ao meio ambiente ecologicamente equilibrado. No Brasil, municípios com população acima de vinte mil habitantes estão obrigados a ter um plano diretor de suas atividades. Neste artigo, utilizando-se o método hipotético-dedutivo através da análise da legislação e da doutrina, procura-se averiguar se as ações contidas neste valioso instrumento têm sido eficientes, no que toca à proteção do meio ambiente, ou se não vêm sendo cumpridas, sob alegações como a falta de recursos orçamentários. Partindo do pressuposto de que o meio ambiente ecologicamente equilibrado é 
direito fundamental reconhecido na Constituição Federal brasileira, o estudo constata que a maior parte das deliberações deste instrumento não vem sendo realizadas e aponta medidas que podem contribuir para imprimir maior eficácia na execução do plano diretor.

RESUM: L'objectiu principal d'aquest estudi és analitzar els aspectes més importants del pla director participatiu, un instrument per assolir l'ordenació urbà i garantir el dret a un entorn ecològicament equilibrat. Al Brasil, els municipis amb més de vint mil habitants han de tenir un pla director per a les seves activitats. En aquest article, utilitzant el mètode hipotètic-deductiu mitjançant l'anàlisi de la legislació i la doctrina, intentem esbrinar si les accions d'aquest valuós instrument han estat eficients pel que fa a la protecció del medi ambient o si no s'han complert, segons allegacions com la manca de recursos pressupostaris. Partint de la suposició que l'entorn ecològicament equilibrat és un dret fonamental reconegut a la Constitució Federal brasilera, l'estudi conclou que la majoria de les deliberacions d'aquest instrument no s'han dut a terme i apunta mesures que poden contribuir a millorar l'eficiència de l'execució del pla director.

RESUMEN: El objetivo principal de este estudio es el de analizar los aspectos más importantes del plan director participativo, como instrumento para la consecución de la ordenación urbana y garantía del derecho al medio ambiente ecológicamente equilibrado. En Brasil, municipios con población superior a veinte mil habitantes están obligados a tener un plan director de sus actividades. En este artículo, utilizando el método hipotético-deductivo a través del análisis de la legislación y de la doctrina, se busca averiguar si las acciones contenidas en este valioso instrumento han sido eficientes, en Iññña la protección del medio ambiente, o si no se han cumplido, bajo alegaciones como la falta de recursos presupuestarios. El estudio constata que la mayoría de las deliberaciones de este instrumento no vienen siendo realizadas y señala medidas que pueden contribuir a imprimir mayor eficacia en la ejecución del plan director.

ABSTRACT: The main aim of this study is to analyze the most important aspects of the participatory master plan, as an instrument for the achievement of urban planning and a guarantee to the right to an ecologically balanced environment. In Brazil, it is mandatory for municipalities with more than twenty thousand inhabitants to have a master plan of their activities. The present article, using the 
hypothetic-deductive method, through the analysis of legislation and doctrine, seeks to verify if the actions contained in tat valuable instrument have been efficient, in regard to the protection of the environment, or if they have not been fulfilled, under allegations such as lack of budgetary resources. Based on the assumption that the ecologically balanced environment is a fundamental right recognized in the Brazilian Federal Constitution, the study finds that most of the deliberations of this instrument have not been carried out and points out measures that may contribute to greater effectiveness in the enforcement of the master plan.

PALAVRAS-CHAVE: Direito Urbanístico - Plano Diretor - Meio ambiente urbano - Estatuto da Cidade.

PARAULES CLAU: Dret Urbanístic - Pla Director - Medi ambient urbà - Estatut de la Ciutat.

PALABRAS CLAVE: Derecho Urbanístico - Plan Director - Medio ambiente urbano - Estatuto de la Ciudad.

KEYWORDS: Urbanistic Law - Master Plan - Urban Environment - City Statute.

SUMARIO: I Introdução. II. O Estatuto da Cidade e a obrigatoriedade de elaboração do Plano Diretor. III. A importância do planejamento para o desenvolvimento das cidades. IV. Obstáculos à efetiva implementação do Plano Diretor pelos municípios. V. Mecanismos para a efetivação do Plano Diretor. VI. Considerações finais. VII. Bibliografia.

\section{INTRODUÇÃO}

A Constituição Federal brasileira de 1988 trouxe clara a preocupação com o crescimento ordenado dos Municípios, com o objetivo de valorizar os espaços públicos, possibilitar a integração do meio ambiente, ${ }^{1}$ ordenar o pleno

\footnotetext{
1 O meio ambiente será compreendido, neste trabalho, no seu conceito amplo, definido por Vladimir Passos de Freitas, compreendendo urbanismo, aspectos históricos, paisagísticos e outros tantos essenciais à sobrevivência sadia na Terra. Vladimir Passos de Freitas, $A$ Constituição Federal e a efetividade das normas ambientais, Revista dos Tribunais. São Paulo, 2005 (5 $5^{\underline{a}}$ edição), p. 15.
} 
desenvolvimento das funções sociais da cidade e garantir o bem-estar de seus habitantes. Essas diretrizes culminaram na elaboração da Lei no 10.257/2001, denominada Estatuto da Cidade, que regulamentou o artigo 182 da Constituição Federal, em cuja redação encontra o feixe de luz que deve nortear as atuações públicas e privadas para a gestão das cidades, principalmente no que se refere à necessidade da existência do plano diretor como instrumento básico da política de desenvolvimento e de expansão urbana.

O plano diretor é, portanto, um meio para se alcançar o desenvolvimento de uma cidade e, sobretudo, obter o chamado desenvolvimento sustentável dos sistemas urbanos. E na busca de tal objetivo, não se pode olvidar o uso da tecnologia, cuja evolução nos surpreende a cada dia. As chamadas cidades inteligentes usam essas novas ferramentas para tornar mais eficiente a infraestrutura dos centros urbanos, dotá-los de maior segurança e de condições de aproveitamento de recursos naturais, tudo de forma a trazer melhores condições de vida aos seus habitantes.

Considerando que a elaboração do plano diretor participativo é obrigação legal para as hipóteses previstas na Lei 1.257/2001, é necessário analisar a eficácia de tais instrumentos e a efetiva implantação das medidas neles contidas, buscando apontar mecanismos que permitam uma maior efetividade das políticas públicas de desenvolvimento urbano.

Diante deste cenário, o objetivo da presente pesquisa é analisar a importância do plano diretor e do planejamento urbano para a garantia do direito ao meio ambiente ecologicamente equilibrado, de modo a verificar quais são os maiores desafios enfrentados na sua efetiva implementação e apontar algumas diretrizes que possam contribuir para otimizar a execução destes instrumentos legislativos.

O problema de pesquisa está lastreado na premissa de que, embora amplamente regulamentado pela legislação brasileira, e contendo, inclusive, previsão constitucional, a implementação dos planos diretores não tem ocorrido de forma satisfatória. Não raro, a execução das medidas previstas no plano diretor fica limitada em razão da sua má elaboração ou sob a alegação de falta de recursos orçamentários, principalmente em tempos de crise econômica. Essa disparidade em relação ao conteúdo previsto no plano diretor e ao que realmente é implementado coloca em xeque a concretização do direito ao meio ambiente 
ecologicamente equilibrado, o que justifica a seguinte indagação: quais são as principais causas da ausência de efetividade na implementação dos planos diretores no Brasil, e quais mecanismos poderiam ser utilizados para possibilitar maior eficácia no seu processo de elaboração e execução?

O presente estudo pauta-se por uma moldura analítico-critica. A ideia central é não se restringir a uma mera verificação da conjuntura normativa-institucional ou a um mero trabalho descritivo, mas sim ultrapassar as barreiras da dogmática estabelecida a fim de propor soluções efetivas para as novas questões suscitadas pela inefetividade da implementação dos planos diretores. Neste sentido, optou-se por uma finalidade mais ampla, na medida em que se acredita possível uma proposta crítica-normativa aos desafios apresentados no problema de pesquisa. O método de pesquisa utilizado é o hipotético-dedutivo, caracterizado pelo emprego de cadeias de raciocínio, que leva o pesquisador do conhecido para o desconhecido, com a utilização da técnica de pesquisa indireta e qualitativa, através de expedientes metodológicos constitutivos da pesquisa bibliográfica, como a coleta e análise de doutrina e acervos legislativos relacionados à problemática em estudo.

Assim, são apresentadas reflexões sobre a importância e eficácia do plano diretor, principalmente no que atine à sua execução, bem como apontam-se os principais entraves enfrentados para a concretização das medidas previstas nos instrumentos legais de ordenamento urbano. Ao final, são apontadas premissas que podem contribuir para a melhoria da gestão e implementação do plano diretor, como forma de fomentar o debate da efetividade de tais medidas e a concretização do direito ao meio ambiente ecologicamente equilibrado.

\section{O ESTATUTO DA CIDADE E A OBRIGATORIEDADE DE ELABORAÇÃO DO PLANO DIRETOR}

A gestão do ambiente urbano configura-se como grande desafio, cabendo à administração pública ações efetivas relacionadas ao planejamento municipal. No Brasil, entre as ferramentas voltadas para o planejamento municipal, destaca-se a Lei Federal oㅜ 10.257/2001, denominada Estatuto da Cidade, que tem como um de seus instrumentos o plano diretor. 
A previsão do Estatuto amolda-se à Constituição da República, que no artigo $182, \S 1 \stackrel{0}{ }$, combina a necessidade de planejamento urbano, ${ }^{2}$ quando o classifica como instrumento básico da política de desenvolvimento e de expansão urbana.

Na concepção de Paulo Affonso Leme Machado, o plano diretor é "um conjunto de normas obrigatórias, elaborado por lei municipal específica, integrando o processo de planejamento municipal, que regula as atividades e os empreendimentos do próprio Poder Público Municipal e das pessoas físicas ou jurídicas", a serem levados a efeito no território municipal. ${ }^{3}$ Em sentido análogo, Hely Lopes Meirelles define Plano Diretor como sendo o "complexo de normas legais e diretrizes técnicas para o desenvolvimento global e constante do Município, sob os aspectos físico, social, econômico e administrativo, desejado pela comunidade local." ${ }^{4}$

O plano diretor dos municípios objetiva ordenar o adequado funcionamento das cidades, aliando função socioambiental, bem-estar dos munícipes e necessidades sociais básicas e, com isso, garantir a condução das políticas públicas municipais para o desenvolvimento sustentável.

Como registra o artigo 40 do Estatuto da Cidade, o Plano Diretor é "o instrumento básico da política de desenvolvimento e de expansão urbana", e prevê uma série de instrumentos para a garantia, no âmbito de cada Município, do direito à cidade, da defesa da função social da cidade e da propriedade e da democratização da gestão urbana, do patrimônio cultural e do meio ambiente, considerando que é o Município o lugar privilegiado para a solução dos problemas urbanos e ambientais nacionais.

De acordo com o artigo 41 do Estatuto da Cidade, o Plano Diretor é obrigatório para cidades com mais de vinte mil habitantes; integrantes de regiões metropolitanas e aglomerações urbanas; onde o Poder Público municipal

\footnotetext{
${ }^{2}$ A expressão "planejamento urbano" surge na Inglaterra e nos Estados Unidos, conferindo um novo enfoque à compreensão da cidade e dos seus problemas e reconhecendo o dinamismo do fenômeno urbano, onde a cidade é fruto de sua própria história que também evolui no tempo sendo vista como produto de um determinado contexto histórico diferentemente do modelo ideal concebido pelos urbanistas. Maria Elaine Kohlsdorf; Ricardo Libanês Farret; Suely Franco Netto Gonzalez; Frederico Rosa Borges de Holanda, O Espaço da cidade: contribuição à análise urbana, Projeto Editores Associados. São Paulo, 1985, p. 141.

${ }^{3}$ Paulo Affonso Leme Machado, Direito Ambiental Brasileiro, Malheiros. São Paulo, 2016 (24a edição), p. 453.

${ }^{4}$ Hely Lopes Meirelles, Direito de Construir, Malheiros. São Paulo, 2011, p.115.
} 
pretenda utilizar os instrumentos previstos no $\S 4^{\circ}$ do artigo 182 da Constituição Federal (parcelamento ou edificação compulsórios, imposto sobre a propriedade predial e territorial urbana progressivo no tempo, desapropriação com pagamento mediante títulos da dívida pública); integrantes de áreas de especial interesse turístico; inseridas na área de influência de empreendimentos ou atividades com significativo impacto ambiental de âmbito regional ou nacional, e; incluídas no cadastro nacional de Municípios com áreas suscetíveis à ocorrência de deslizamentos de grande impacto, inundações bruscas ou processos geológicos ou hidrológicos correlatos.

Cumpre aos planos diretores estabelecer normas cujo cumprimento acabe por efetivar o princípio da função social da propriedade. São as normas do plano diretor que definirão os limites, as faculdades, as obrigações e as atividades que devem ser desenvolvidas pelos proprietários de imóveis para que as respectivas propriedades atinjam sua função social. ${ }^{5}$

A partir destes pressupostos, é possível mencionar que o Plano Diretor possui duas categorias de normas distintas: aquelas que impõem obrigações aos particulares, direcionadas, principalmente, ao cumprimento da função social da propriedade, e; aquelas que impõem obrigação ao Estado, no sentido de implementar ações e ofertar prestações positivas à sociedade com o objetivo de garantir a sadia qualidade de vida.

Como visto, as cidades detentoras do Plano Diretor obrigatório são somente aquelas enquadradas nas hipóteses do artigo 41 do Estatuto da Cidade. Tal instrumento é facultado nas demais localidades. Neste contexto, salienta-se a dificuldade em atender à função social da propriedade urbana, bem como ao ordenamento local em municípios sem o planejamento dado a partir do Plano Diretor municipal. Conforme aponta Ruy Jesus Marçal Carvalho, "o ideal seria que todas as cidades, independentemente de seu contingente populacional, estivessem obrigadas a dispor deste instrumento."6

\footnotetext{
${ }^{5}$ Priscila Ferreira Blanc, Plano Diretor Urbano e Função Social da Propriedade, Juruá Editora. Curitiba, 2004, p. 118.

${ }^{6}$ Janaína Rigo Santin; Letícia Virgínia Leidens, "Plano Diretor: instrumento de efetivação da função social da propriedade urbana e participação popular" en Revista Brasileira de Direito Municipal (RBDM) 20 (abr./ jun. 2006).
} 
No Brasil, o foco no desenvolvimento prioritariamente econômico ${ }^{7}$ associados aos processos de exploração e transformação dos recursos naturais, desassistidos de políticas públicas balizadoras, imprimiu, ao longo dos anos, forte insustentabilidade ambiental. Em outros termos, não houve planejamento de projetos articulados visando o desenvolvimento integral, mas ao contrário, prevaleceu a difusão do desenvolvimentismo, condutor da urbanização e industrialização.

Bom exemplo da deficiência de Plano Diretor adequado é a ausência de delimitação de zona industrial. Tal fato eleva o nível de poluição do ar, e isto nem sempre é perceptível. Nas palavras de Édis Milaré, a poluição atmosférica "é o retrato negativista da civilização industrial que tão fortemente condiciona o nosso estilo de vida". Toneladas de "emissões de elementos sólidos e gasosos alteram, passageiramente ou de forma estável, as condições de vida e influenciam nas atividades produtivas". Por exemplo, o "monóxido de carbono (CO) é o poluente característico dos grandes centros urbanos, sempre presente apesar de incolor, insípido e inodoro, emitidos por fontes estacionárias" presente em indústrias e "fonte móveis" constantes de veículos automotores". 8

Estas características dificultam e condicionam a resolução dos problemas ambientais no ambiente urbano que dependem não só de soluções técnicas, mas de um processo de gestão visando prevenir e solucionar os problemas ambientais urbanos, considerando que a gestão envolve uma escala socioeconômica e política. ${ }^{9}$

\footnotetext{
${ }^{7}$ Vale aqui a crítica feita por Emerson Gabardo, no sentido de que, do ponto de vista conceitual, a expressão "desenvolvimento econômico" não é a mais correta, uma vez que "não existe desenvolvimento apenas de caráter econômico". Portanto, não há qualquer sentido em se referir ao desenvolvimento como "apenas econômico, ou apenas político, ou apenas social". Emerson Gabardo, Interesse público e subsidiariedade: a sociedade civil para além do bem e do mal, Fórum. Belo Horizonte, 2009, p. 245. Na mesma linha, Carla Abrantkoski Rister aduz que o direito ao desenvolvimento vai além do conceito de desenvolvimento puramente econômico, visto que pressupõe uma aproximação centrada nos direitos humanos. Neste sentido, seria necessário, ao se pensar o desenvolvimento, ter em mente paz, economia, meio ambiente, justiça e democracia. Carla Abrantkoski Rister, Direito ao desenvolvimento: antecedentes, significados e consequências, Editora Renovar. Rio de Janeiro, 2007, p. 67.

${ }^{8}$ Édis Milaré, Direito do ambiente, Revista dos Tribunais. São Paulo, 2013 (8 edição), p. 518.

9 José Eduardo Ramos Rodrigues; Valdir Fernandes; Arlindo Philippi Júnior, "Política e gestão ambiental no Brasil", en Alessandra Galli, Direito Socioambiental: Homenagem a Vladimir Passos de Freitas, Juruá Editora. Curitiba, 2010, p. 397.
} 
O estágio atual do crescimento urbano e industrial é o resultado desse processo. Os problemas ambientais urbanos, especialmente os associados ao uso e ocupação do solo sem planejamento em áreas urbanas, cujos resultados são os mais diversos, desde a formação de favelas, até poluição e degradação de áreas verdes e rios. ${ }^{10}$

A partir do exposto, por contingência e natureza das relações estabelecidas no meio urbano, depende-se de políticas integradas de desenvolvimento urbano e industrial e de ações articuladas, que contemplem no processo de desenvolvimento a dimensão ambiental. É neste contexto que a implementação do Plano Diretor assume crucial importância para o desenvolvimento ordenado das cidades e para a correção de problemas urbanísticos decorrentes da falta de políticas de planejamento anteriores.

A função urbanística é exercida de forma mais direta e concreta no âmbito municipal. Os planos diretores, portanto, originaram-se dos planos de desenvolvimento urbano que determinavam regras para o desenvolvimento físico das cidades, vilas e outros núcleos urbanos do Município ${ }^{11}$.

A partir de um resgate histórico, Priscila Ferreira Blanc lembra que, inicialmente, a preocupação dos planos era com a questão do desenho da cidade, evoluindo para a disposição das edificações no território e, chegando até a ideia do desenvolvimento integrado dos campos físico, econômico, social e administrativo. Diferentemente de tudo isso, o Plano Diretor da Constituição Federal de 1988 adquire a importância de instrumento garantidor do bem-estar da população e principal meio de se atingir o pleno desenvolvimento das funções sociais da cidade, conforme disposto em seu art. 182 , § 1‥12

\footnotetext{
${ }^{10}$ Rodrigues; Fernandes; Philippi Júnior, "Política e gestão..., cit., p. 397.

${ }^{11}$ Com a aprovação do Estatuto da Cidade em 2001, os Planos Diretores Municipais passaram a abranger, também, a totalidade do território municipal, ou seja, suas áreas urbanas e rurais. Coube ao Plano Diretor incluir em seu contexto, o ordenamento e o disciplinamento do uso e da ocupação do território rural dos municípios, bem como o auxílio no desenvolvimento econômico desses espaços, por meio de legislações e resoluções federais ou estaduais. Amanda Pires Mesquita; William Rodrigues Ferreira, "O Município e o planejamento rural: o plano diretor municipal como instrumento de ordenamento das áreas rurais", en Espaço em Revista 18 (n. 1, jan/jun. 2016), p. 11-32.

12 Priscila Ferreira Blanc, Plano Diretor Urbano e Função Social da Propriedade, Juruá Editora. Curitiba, 2004, p. 130.
} 
$\mathrm{O}$ direito à cidade compreende os direitos inerentes às pessoas que vivem nos centros urbanos de ter condições dignas de vida, de exercitar plenamente a cidadania, de criar, ampliar os direitos fundamentais (individuais, econômicos, sociais, políticos e ambientais), de participar da gestão da cidade, e de viver num meio ambiente sadio ecologicamente equilibrado e sustentável. ${ }^{13}$

Como lembra Tiago Fensterseifer, a Constituição Federal brasileira de 1988, no marco jurídico de um constitucionalismo ecológico, atribuiu ao direito do ambiente o status de direito fundamental (formal e materialmente) do indivíduo e da coletividade, reconhecendo posições jurídicas subjetivas justificáveis dele decorrentes. De mesmo modo, a Lei Fundamental consagrou a proteção ambiental como um dos objetivos e tarefas mais importantes do Estado de Direito brasileiro, incorporando os valores ecológicos no núcleo axiológico do nosso sistema constitucional. Neste contexto, o autor lembra que o direito ambiental, por sua vez, caracteriza-se como direito fundamental de terceira dimensão, tendo como fundamento axiológico o princípio constitucional da solidariedade e a natureza de um direito transindividual (e mesmo universal). O processo de afirmação histórica dos direitos fundamentais e a caracterização do Estado socioambiental em superação aos modelos de Estado Liberal e Social justificam tal perspectiva constitucional. ${ }^{14}$

Essa mudança do modo de olhar a cidade causou profundas alterações quanto à importância do planejamento urbanístico. Não se pode mais atuar no improviso, apenas reagindo aos acontecimentos que, não raro, produzem efeitos nefastos para a cidade e sua população. Ao exigir a elaboração de planos diretores, a Constituição Federal exige também o planejamento, eis que aquele é apenas a instrumentalização deste. ${ }^{15}$

Por isso, tem razão Toshio Mukai ao afirmar que a Lei n. ${ }^{0}$ 10.257/01 veio para tornar exequível o que dispõe o art. 182, não somente para estabelecer as diretrizes reclamadas por essa disposição constitucional, como ainda para tornar

\footnotetext{
${ }^{13}$ Nelson Saule Júnior, Direito à cidade: trilhas legais para o direito às cidades sustentáveis, Max Limonad. São Paulo, 1999, p. 118.

14 Tiago Fensterseifer, Direitos fundamentais e proteção ambiental: $A$ dimensão ecológica da dignidade humana no marco jurídico-constitucional do Estado Socioambiental de Direito, Livraria do Advogado Editora. Porto Alegre, 2008, p. 29.

${ }^{15}$ Blanc, "Plano Diretor Urbano...", cit., p. 131.
} 
também efetivo, no plano jurídico-positivo, a concretização do princípio da função social da propriedade, já que torna também exequível a obrigatoriedade da existência do Plano Diretor, como veremos, e finalmente, regulamenta a urbanização compulsória, prevista no $\S 4^{\circ}$ do art. 182 da Constituição Federal e, ainda, a figura da usucapião urbana prevista no artigo $183 .{ }^{16}$

Todavia, Liana Portilho Mattos chama a atenção para a possibilidade de uma interpretação equivocada do artigo 182, § 2º,da Constituição Federal, e também do artigo 39, do Estatuto da Cidade, que pode induzir ao entendimento de que a propriedade urbana cumpre sua função social somente quando atende às exigências do plano diretor, ou seja, os Municípios que não estão legalmente obrigados a elaborar planos diretores, ou aqueles que, mesmo sujeitos a essa obrigação, ainda não a tenham cumprido, estariam sujeitos à inefetividade da função social da propriedade. Esta interpretação, além de absurda, é totalmente desprovida de sentido jurídico, pois o plano diretor não é o único instrumento de efetividade da função social da propriedade urbana, devendo esta ser observada independentemente da existência ou não de plano diretor aprovado. ${ }^{17}$

\section{A IMPORTÂNCIA DO PLANEJAMENTO PARA O DESENVOLVIMENTO DAS CIDADES}

O planejamento urbano é um importante instrumento de promoção de mudanças significativas nas cidades brasileiras para obter o desenvolvimento sustentável e a criação de uma nova relação do homem com o meio ambiente em que vive. No que concerne a este planejamento, o Plano Diretor é a ferramenta básica para o ordenamento das cidades, estabelecendo diretrizes a fim de atender as necessidades dos cidadãos, garantindo qualidade de vida e desenvolvimento econômico-social.

O marco inaugural da necessidade de se pensar o planejamento urbano no Brasil foi o fim do século XIX, quando se inicia a transformação da economia nacional, que deixa de ser unicamente agroexportadora e inicia o processo de

\footnotetext{
${ }^{16}$ Toshio Mukai, "Planejamento municipal: o plano diretor e o Estatuto da Cidade", en Fórum de Direito Urbano e Ambiental 1, (jan./fev. 2002).

${ }^{17}$ Liana Portilho Mattos, $A$ efetividade da função social da propriedade urbana, Temas \& Ideias. Rio de Janeiro, 2003, p. 110.
} 
industrialização. Com a economia agrária em decadência, o homem do campo, à procura de trabalho e melhor condição de sobrevivência, muda-se para o perímetro urbano. Esta concentração populacional nos centros urbanos faz crescer a demanda por novas moradias. Assim, na tomada de responsabilidade individual, a solução encontrada por trabalhadores foi a ocupação de moradias coletivas e insalubres.

As primeiras ações de planejamento urbano no Brasil estão direcionadas ao embelezamento da cidade, com vistas a exaltar a burguesia e dar ao espaço urbano caracteres de identidade progressista, semelhante às outras cidades cosmopolitas no mundo. ${ }^{18}$

Esta visão calcada apenas no aspecto estético urbano se contrapõe totalmente à visão de planejamento urbano contemporânea. A ordenação da cidade diante dos instrumentos legislativos atuais exige a definição de parâmetros e diretrizes comuns da política urbana, planejamento urbano, garantias da participação democrática no planejamento, instrumentos jurídicos, orçamentários, financeiros e políticos, e regularização fundiária de regiões ocupadas e não titularizadas por seus ocupantes no solo da cidade.

O Brasil possui atualmente cinco mil quinhentos e setenta municípios que ainda têm pouca experiência de gestão local de seu desenvolvimento e da ocupação de seu espaço. Como em outros setores, são enormes os desafios à sustentabilidade nas cidades brasileiras. O processo de expansão urbana nas últimas quatro décadas, fruto de um imenso êxodo rural e de disparidades regionais de renda, determinou a ocupação desordenada do solo pelas populações de baixa renda migrantes, que em seguida, passaram a pressionar os governos pela implantação de todas as infraestruturas sociais (educação, saúde, habitação, abastecimento de água, saneamento, transporte, drenagem,

\footnotetext{
${ }^{18}$ São obras urbanas características desse período: a criação de uma autoridade executiva de saneamento no Rio de Janeiro para promover obras de drenagem e aterro dos terrenos baixos e alagadiços; abastecimento de água potável, conservação de florestas; sindicância no sistema de esgoto da cidade; destruição do lixo removido; calçamento e lavagem cotidiana das ruas; alargamento de ruas e ampliação dos espaços públicos como forma de melhorar a ventilação da cidade; saneamento em habitações com a elaboração de legislação de controle de edificações e auxilio a empresas que quisessem construir habitações para a população de baixa renda. Patrícia Gabai Venâncio, O Direito à Moradia Digna: um novo paradigma de atuação do Ministério Público à luz da gestão democrática da cidade, Dissertação de Mestrado em Direito da Cidade, Universidade do Estado do Rio de Janeiro. Rio de Janeiro, 2009, p. 16.
} 
limpeza urbana, segurança e lazer). A deterioração progressiva das finanças públicas coincidindo com o não atendimento das demandas gerou direitos sociais não atendidos.

A proteção à ordem urbanística, de acordo com os esclarecimentos de José Carlos Freitas envolve o direito às cidades sustentáveis, a um planejamento urbanístico (notadamente elaboração, execução e implementação dos planos diretores e seu controle popular); ao uso, ocupação e parcelamento do solo urbano funcionais e ordenados; à proteção do ambiente natural, artificial e cultural; à ordenação da atividade edilícia (zoneamento urbano e ambiental, licenças urbanísticas); à utilização de instrumentos de intervenção urbanística (desapropriação, tombamento, servidão administrativa, IPTU progressivo e desapropriação-sanção); ao regramento e proteção dos equipamentos comunitários e bens públicos ou sociais (ruas, avenidas, pontes, viadutos, túneis, parques, praças, jardins, lagos, áreas verdes e institucionais, espaços livres); ao direito à moradia, notadamente das camadas sociais de baixa renda ${ }^{19}$.

Plano Diretor e planejamento estão fortemente entrelaçados. Com efeito, estatui o $\S 1^{\circ}$ do artigo 40 do Estatuto da Cidade que o "plano diretor é parte integrante do processo de planejamento municipal, devendo o plano plurianual, as diretrizes orçamentárias e o orçamento anual incorporar as diretrizes e as prioridades nele contidas". O cuidado do Estatuto da Cidade, nesse particular, é plenamente justificável, pois a execução do Plano Diretor pode exigir recursos orçamentários e, a seu tempo, financeiros. Este é um dos grandes entraves à efetiva execução do plano diretor, conforme será abordado adiante.

O plano diretor como instrumento do planejamento participativo, para garantir o direito da comunidade participar de todas as fases do processo, deve conter mecanismos democráticos que permitam o prática da cidadania ativa, compreendendo mecanismos referentes à sua fase de elaboração, tais como o direito a obter informações, de apresentar proposições a emendas; as

\footnotetext{
${ }^{19}$ José Carlos de Freitas, "Estatuto da cidade e improbidade administrativa", em Temas de direito urbanístico, Ministério Público do Estado de São Paulo, Imprensa Oficial do Estado. São Paulo, 2005.
} 
audiências públicas e o referendo, bem como referentes à sua fase de execução e revisão através do sistema de planejamento democrático. ${ }^{20}$

Inclui-se no planejamento o estabelecimento de diretrizes e rumos, o estudo de problemas, a programação de soluções, a viabilização de obras e serviços, enfim, a adoção de medidas que possam levar ao atingimento dos objetivos propostos. Nesse sentido, o planejamento urbanístico não é um ato isolado, que se realiza apenas em determinado momento, mas, antes, é uma atividade contínua e infindável, razão pela qual é definida como um processo. Os planos, enquanto instrumentos do planejamento, adquirem forma e, no caso do plano diretor municipal, adquirem também força de lei, como se verá mais a fundo no tópico que tratará da sua aprovação. O planejamento dá ideia de uma ação prolongada no tempo, que sobrevive aos governos, que são temporários. ${ }^{21}$

O estabelecimento de metas tornou-se instrumento de vital importância para a ação planejada de autoridades públicas, sobretudo as municipais. O prefeito deve possuir um método de ação que se coadune com o planejamento local (plano diretor), a leis orçamentárias e o plano plurianual. Deve igualmente considerar a lei orgânica local. E, como bem afirmou José Afonso da Silva, "esses instrumentos, coordenados com o plano diretor, na verdade, funcionam também como instrumentos de execução deste."22

Planejar o desenvolvimento da cidade tem por objetivo evitar e corrigir as distorções do crescimento urbano e seus impactos sobre o meio ambiente. A ordenação e o controle do uso do solo disciplinam a instalação e o desenvolvimento dos empreendimentos e atividades no espaço da cidade, a fim de conter o avanço da poluição e de outros danos ambientais. ${ }^{23}$

Nesta perspectiva, Gilberto Bercovici infere que o planejamento exige um Estado forte, capaz de direção e coordenação. Para promover o desenvolvimento, devem ser reformulados as funções do Estado, bem como deve ser reestruturado o seu instrumental, o que não significa procurar a equiparação

\footnotetext{
${ }^{20}$ Saule Júnior, "Direito à cidade..." cit., p. 118.

${ }^{21}$ Blanc, "Plano Diretor Urbano...", cit., p. 131.

22 José Afonso da Silva, Direito urbanístico brasileiro, Malheiros. São Paulo, 2006, p. 148.

${ }^{23}$ Maria Luiza Machado Granziera, Direito Ambiental, Atlas. São Paulo, 2011, p. 617.
} 
imitativa com os países desenvolvidos. É uma tarefa extremamente complexa, mas absolutamente necessária. ${ }^{24}$

A relação entre o planejamento e o seu objeto assume, neste contexto, caráter plenamente dinâmico, na medida em que a própria ação estatal oriunda de planejamentos pretéritos acaba por modificar e readequar a situação objeto, pelo que o planejamento estatal deve estar constantemente em processo de atualização.

\section{OBSTÁCULOS À EFETIVA IMPLEMENTAÇÃO DOS PLANOS DIRETORES PELOS MUNICÍPIOS}

Os princípios fundamentais norteadores do plano diretor estão lastreados nos princípios constitucionais da política urbana preconizados nos fundamentos do Estado Democrático de Direito, da cidadania e dignidade da pessoa humana, nos princípios da soberania popular e da igualdade, voltados a proteger e tornar concreto o exercício do direito à cidade e garantir o meio ambiente sadio e ecologicamente equilibrado. ${ }^{25}$

A obrigatoriedade de elaboração do plano diretor prevista no Estatuto da Cidade parte da ideia de dever do município de promover uma legislação para o planejamento municipal, visando sempre atingir a função social da cidade e da propriedade urbana, com vistas ao bem-estar social. ${ }^{26}$ Assim, cabe ao Município a elaboração do plano diretor, a sua instituição mediante lei e, certamente e com maior razão, também the compete a implantação e a fiscalização de suas regras. ${ }^{27} \mathrm{~A}$ implantação do plano diretor não é outra coisa senão a observância

\footnotetext{
${ }^{24}$ Gilberto Bercovici, Desigualdades regionais, Estado e constituição, Max Limonad. São Paulo, 2003, p. 192.

${ }^{25}$ Saule Júnior, "Direito à cidade..." cit., p. 117.

${ }^{26}$ Santin; Leidens, "Plano Diretor: instrumento..., cit.

${ }^{27}$ Entre as diretrizes que devem ser observadas pelos planos diretores estão: a garantia do direito a cidades sustentáveis, ao saneamento ambiental, à moradia, à gestão democrática da cidade, planejamento do desenvolvimento das cidades, ordenação e controle do uso do solo evitando a utilização inadequada dos imóveis urbanos, a proximidade de usos incompatíveis ou inconvenientes, a retenção especulativa de imóvel urbano, a poluição e a degradação ambiental; justa distribuição dos benefícios e ônus decorrentes do processo de urbanização; proteção, preservação e recuperação do meio ambiente natural e construído, do patrimônio cultural, histórico, artístico, paisagístico e arqueológico; regularização fundiária e urbanística de áreas ocupadas por população de baixa renda; simplificação da legislação de parcelamento, uso e ocupação do solo e das normas edilícias, visando a redução de custos e o aumento de ofertas dos lotes e unidades habitacionais; isonomia das condições para os agentes públicos e privados
} 
e execução de suas disposições, estando em vigor a respectiva lei. Para essa implantação, podem ser necessárias a edição de leis específicas, de regulamentos de execução e a elaboração de planos executivos.

A implantação pode ir desde a instituição de leis específicas, como a prevista no artigo $5^{\circ}$ do Estatuto da Cidade, destinada a disciplinar, em área descrita no plano diretor, o parcelamento, a edificação ou a utilização compulsórios do solo urbano não edificado, subutilizado ou não utilizado, até a transformação, no centro urbano, de uma rua em local de convívio social que, na linguagem coloquial, se convencionou chamar de calçadão.

A fiscalização compreende o exercício do poder de polícia municipal, tendo em vista conformar a atuação das pessoas físicas e jurídicas, inclusive as que possuem personalidade jurídica de Direito Público (União, Estado, Distrito Federal, Municípios e autarquias), as governamentais (empresa pública, sociedade de economia mista) e privadas (sociedades mercantis, industriais, prestação de serviços) aos termos, condições e procedimentos prescritos e regulados pela lei do Plano Diretor e seus regulamentos. ${ }^{28}$

Todavia, apesar da existência de um excelente conjunto normativo tratando da necessidade de consecução do desenvolvimento sustentável e da realização da justiça social para os espaços urbanos e rurais, o Brasil ainda está distante de vislumbrar a efetividade do planejamento do ordenamento territorial e do processo de ocupação do território brasileiro, como forma de propiciar condições de vida, lazer, habitação e trabalho de forma digna, a todos os brasileiros.

Os inúmeros conflitos decorrentes do processo de ocupação do solo apontam para os diversos desafios, paradoxos, impossibilidades e limitações jurídicoinstitucionais em torno da implementação de políticas públicas para os espaços urbanos e rurais, em bases sustentáveis, pois apesar de existir um avançado

na promoção de empreendimentos e atividades relativos ao processo de urbanização, atendido o interesse social. Mukai, "Planejamento municipal...", cit.

${ }^{28}$ Diógenes Gasparini, "Aspectos Jurídicos do Plano Diretor", en Interesse Público - IP 31 (ano 7, maio / jun. 2005). Disponível em: <http://www.bidforum.com.br/PDI0006.aspx?pdiCntd=49975>. [Último acesso em: $12 \mathrm{dez}$. 2020]. 
marco legislativo direcionador para a construção da ordem urbanística, o Direito brasileiro não tem sido capaz de assegurar a ordenação justa da sociedade. ${ }^{29}$

As limitações inerentes aos processos concretizadores do ordenamento e do planejamento territorial, no sistema jurídico brasileiro, são diversas. Note-se, nesta perspectiva, que a instituição do Plano Diretor visa, como é natural e óbvio, à sua implantação, pois não é racional a instituição de uma lei senão para vê-la atendida em seus termos e condições. Daí a atenção com sua exequibilidade. Esta deve ser a maior preocupação dos seus mentores, pois o Plano Diretor há de revelar-se viável, exequível.

Neste cenário, a maioria dos problemas de desenvolvimento urbano verificados nas cidades brasileiras não decorre da inexistência de Plano Diretor, mas sim da inexecução da política de desenvolvimento urbano preconizada por parte dos instrumentos orçamentários capazes de concretizá-la; ou ainda porque é aplicada apenas em parte da cidade, muitas vezes havendo uma concentração de investimentos em áreas já dotadas de infraestrutura em detrimento de áreas precárias. $^{30}$

Disso depreende-se que os planos diretores devem ser exatamente adequados à realidade, às especificidades do Município, considerando as reais necessidades e os obstáculos enfrentados para a satisfação do direito à sadia qualidade de vida de seus habitantes e potenciais problemas futuros. Em outros termos, as ações contidas na Lei Municipal que estabelece o Plano Diretor não podem negligenciar a circunstância fática vivida pelo Município e suas necessidades efetivas.

Assumindo a forma de lei municipal, o plano diretor deve relacionar o conjunto de princípios e regras que orientarão a ação dos atores que constroem e utilizam o espaço urbano. Para tanto, sua elaboração deve partir de uma leitura da cidade real, envolvendo temas e questões relativos aos aspectos urbanos, sociais,

\footnotetext{
${ }^{29}$ Daniella Maria dos Santos Dias, Planejamento e Desenvolvimento Urbano no Sistema Jurídico Brasileiro, Juruá Editora. Curitiba, 2012, p. 144.

${ }^{30}$ Amanda Munhoz Buba, "Construindo a relação entre planejamento orçamentário e Plano Diretor", Revista do Ministério Público de Contas do Estado do Paraná - MPC, v. 6. n. 11, 2019: novembro/maio, p. 34.
} 
econômicos e ambientais, que embasam a formulação de hipóteses realistas sobre as opções de desenvolvimento da cidade.

O objetivo do plano diretor não é resolver todos os problemas urbanos, mas antes ser um instrumento para a definição de uma estratégia para a intervenção pública, estabelecendo poucos e claros princípios de ação para o conjunto dos agentes envolvidos na construção da cidade, servindo também de base para a gestão pactuada da cidade. ${ }^{31}$

De mesmo modo, o plano diretor deve ser exequível. Implica dizer que o documento legal deve levar em consideração, principalmente, o potencial econômico, a capacidade orçamentária e o grau de possibilidade de participação da iniciativa privada na implementação de medidas urbanísticas formuladas. Planos diretores que estipulam obras vultosas e de alto investimento, em Municípios que não dispõem de recursos orçamentários ou provisão de recursos para tanto estão fadados a tornarem-se mera norma de caráter programático, sem nenhuma aplicabilidade. É o chamado "plano discurso", que atende a um imperativo legal e cumpre um papel ideológico, estando desvinculado da gestão urbana e distante da prática. ${ }^{32}$

A partir desses pressupostos, o Estatuto da Cidade prevê, que "o plano diretor é parte integrante do processo de planejamento municipal, devendo o plano plurianual, as diretrizes orçamentárias e o orçamento anual incorporar as diretrizes e as prioridades nele contidas".

Importa dizer, portanto, que as ações a cargo do Poder Público que demandem recursos do erário devem estar previstas no orçamento do Município. Obras como a disciplina do sistema viário, acessibilidade, saneamento básico, adequação da oferta de transportes à demanda da população, priorização da circulação do transporte coletivo e do tráfego de passagem nas vias, ordenamento e manutenção permanente da malha viária, construção de praças, dimensionamento de hospitais e postos de saúde, centros sociais, oferta de vagas nos estabelecimentos prestadores de serviços públicos compatível à

31 Terence Dornelles Trennepohl, Fundamentos de direito ambiental, JusPodivm. Salvador, 2007, p. 155.

32 Ermínia Maricato, Brasil, cidades: alternativas para a crise urbana, Vozes. Petrópolis, 2011, pp. 116-117. 
demanda por bairro, transporte coletivo urbano, iluminação pública e coleta e tratamento de resíduos sólidos, devem ser dimensionadas à realidade do Município e incluídas no orçamento.

Todavia, em que pese a obviedade do dispositivo mencionado, é possível afirmar que boa parte das medidas previstas nos planos diretores não são executadas.

Para além da aprovação do plano diretor, o maior desafio é tirá-lo do papel. Um exemplo recorrente é o município mais populoso do país, São Paulo, que ilustra com precisão a dificuldade de execução do plano idealizado. No caso de São Paulo, o Plano Diretor anterior, aprovado em 2002, previa, por exemplo, uma série de operações urbanas para revitalizar áreas da cidade, como a da avenida Celso Garcia, na zona leste da capital. As obras não foram feitas, e a região sofreu degradação. ${ }^{33}$

Consoante expõe Amanda Munhoz Buba, a vivência da cidade demonstra que o debate público no decorrer da elaboração e tramitação do Plano Diretor do Município de São Paulo, bem como após sua aprovação, deu-se majoritariamente ligado aos instrumentos urbanísticos de regulação da atuação privada, principalmente o zoneamento. A parte programática (objetivos e ações públicas previstas para alcançá-los), mais diretamente conectada aos investimentos do orçamento público, foi menos discutida. A própria análise feita no presente estudo demonstrou, ainda, que diversos objetivos constantes do Plano eram apenas "intenções", não havendo sinalização de como se deveria proceder para alcançá-los. ${ }^{34}$ Entretanto, a situação vivenciada por São Paulo não é exceção. A maior parte dos Municípios enfrenta problemas similares, em maior ou menor grau.

Uma das principais causas suscitadas para procurar justificar a não execução do plano diretor é a falta de receita orçamentária. Os Municípios alegam que a arrecadação está abaixo do previsto nas leis orçamentárias, e utilizam tal premissa para explicar a paralização ou o cancelamento de ações previstas. Nos

\footnotetext{
${ }^{33}$ Eduardo Geraque, "Tirar o Plano Diretor do papel será o maior desafio após a aprovação", en Folha de São Paulo (29/06/2014). Disponível em: https://www1.folha.uol.com.br/cotidiano /2014/06/1478137-tirar-o-plano-diretor-do-papel-sera-o-maior-desafio-apos-a-aprovacao.shtml. Acesso em 10/12/2018].

${ }^{34}$ Amanda Munhoz Buba, "Construindo a relação entre planejamento orçamentário e Plano Diretor", em Revista do Ministério Público de Contas do Estado do Paraná - MPC, v. 6 n. 11 (2019): novembro/maio, p. 34.
} 
últimos anos, em decorrência da crise financeira, severamente agravada pela pandemia de COVID-19, que teve como consequência o aumento do desemprego, a desaceleração da economia e a consequente diminuição na arrecadação, esse argumento tem sido retórico.

Em apoio a esta premissa, os gestores públicos alegam que, num critério de ponderação, os recursos existentes devem ser aplicados em pastas mais carentes, como saúde, educação e segurança pública. A um só tempo: as medidas de intervenção ambiental e urbanística, capazes de assegurar o direito à sadia qualidade de vida, acabam relegadas a um segundo plano, como se pertencessem a uma "segunda categoria de direitos".

Não se pode, todavia, respaldar a ideia de que a mera falta de recursos orçamentários justificaria a não execução do plano diretor, e isto se deve a uma série de fatores. Um primeiro aspecto é de caráter financeiro e orçamentário. Isso porque o princípio da exatidão, que rege as finanças públicas, dispõe que as estimativas orçamentárias devem ser tão exatas quanto possível, de forma a garantir à peça orçamentária um mínimo de consistência para que possa ser empregada como instrumento de programação, gerência e controle.

Assim, não se pode aceitar o não cumprimento das ações contidas no Plano Diretor sob o simples argumento de que não há recursos disponíveis para sua execução. O orçamento constitui um conjunto de proposições orientadoras dos processos e de práticas orçamentárias, com vistas a dar-Ihes consistência. Deve, sob a égide do princípio da exatidão, ser um instrumento estável que permita o controle de receitas e despesas. Qualquer alegação de insuficiência de recursos sem a devida comprovação deve ser de pronto refutada e apuradas as responsabilidades dos responsáveis pela formulação do orçamento.

Um segundo aspecto diz respeito à essencialidade dos direitos relacionados à execução do plano diretor. A exigência da elaboração e execução do plano diretor guarda relação íntima com o direito ao meio ambiente ecologicamente equilibrado previsto no artigo 225, caput, da Constituição Federal. 
A doutrina do direito ambiental brasileiro, em geral, classifica o direito ao meio ambiente ecologicamente equilibrado como um direito fundamental. ${ }^{35}$ José Afonso da Silva identifica neste dispositivo constitucional uma norma-matriz, que evidencia um direito fundamental entre os direitos sociais do homem. ${ }^{36}$ No mesmo sentido, Paulo de Bessa Antunes 0 qualifica como um direito fundamental da pessoa humana, de eficácia plena, ${ }^{37}$ como importante marco na construção de uma sociedade democrática e participativa.

O direito à cidade sustentável é o eixo central do Direito Urbanístico para onde convergem outros direitos fundamentais, não se restringindo somente na construção de moradias, para os que não a possui, e na canalização de investimentos para a criação de empregos, fato que, se isoladamente fossem aplicados à realidade atual das cidades brasileiras, já seria um grande avanço. Ele compreende também, a efetivação de direitos civis e sociais, a exemplos do acesso aos meios de transportes públicos amplos e inclusivos, do sistema de educação e de proteção à saúde universal, gratuito e de qualidade, do saneamento básico sustentável para toda a população e a promoção/proteção do meio ambiente equilibrado e sustentável, além de segurança pública ampla e competente e lazer disponível a todos. ${ }^{38}$

A sustentabilidade vem sendo debatida exaustivamente, importando transformações tanto sociais quanto econômicas, políticas, jurídicas, com vistas a alcançar o equilíbrio e a preservação do meio ambiente. Como adverte Juarez Freitas, a sustentabilidade não é um princípio abstrato ou literário, de concretização remota e protelável. Trata-se de um direito fundamental que determina, independentemente de regulamentação legal, com eficácia direta e imediata, a responsabilidade do Estado e da sociedade pela concretização solidária do desenvolvimento material e imaterial, socialmente inclusivo, durável e equânime, ambientalmente limpo, inovador, ético e eficiente, no intuito de

\footnotetext{
35 Marco Túlio Reis Magalhães, "Desafios de concretização do direito (fundamental) ao meio ambiente ecologicamente equilibrado: o exemplo da concessão de florestas e do aquecimento global", en Revista Fórum de Direito Urbano e Ambiental - FDUA 47 (ano 8, set./out. 2009). Disponível em: <http://www.bidforum.com.br/PDI0006.aspx?pdiCntd=63151>. Acesso em: 15 dez. 2018.

36 José Afonso da Silva, Direito ambiental constitucional, Malheiros. São Paulo, 2004, p. 52.

${ }^{37}$ Paulo de Bessa Antunes, Direito ambiental, Lumen Juris. Rio de Janeiro, 2004, pp. 70-71.

${ }^{38}$ Zélia Leocádia da Trindade Jardim, "Regulamentação da política urbana e garantia do direito à cidade", en Direito da Cidade: novas concepções sobre as relações jurídicas no espaço social urbano, Lumen Juris. Rio de Janeiro, 2007.
} 
assegurar, preferencialmente de modo preventivo e precavido, no presente e no futuro, o direito ao bem-estar físico, psíquico e espiritual, em consonância homeostática com o bem de todos"39

A partir desta conjuntura, impõe-se o reconhecimento das ações contidas no plano diretor como instrumento eficaz para a promoção do direito ao meio ambiente ecologicamente equilibrado e da sustentabilidade. Tais direitos devem ser efetivamente concretizados, e não apenas relegados a segundo plano, pois estão intimamente relacionados à dignidade da pessoa humana.

Ademais, é cediço que as medidas previstas no plano diretor servem como promotoras e indutoras de uma série de outros direitos fundamentais, a exemplo do direito à saúde, educação, transporte, assistência social, moradia digna, entre outros. Em outras palavras, por meio das políticas urbanísticas contidas no plano diretor, se efetivam outros direitos que encontram pontos de conexão com a sadia qualidade de vida.

Também não se mostra arrazoado o argumento de que as medidas do plano traçado possam ser postergadas por tratar-se de normas de caráter programático. Conforme ressalta Maria IIma Silva Dias, ao se postergar a aplicação dos instrumentos urbanísticos previstos no Plano Diretor, a implementação deste vem se limitando ao zoneamento e ao controle do uso do solo urbano, bem como de toda a legislação urbanística. E mesmo estes instrumentos têm enfrentado desafios frente às pressões de ordem política e econômica privada, que buscam seus interesses em detrimento dos princípios sociais que visam a organização e o controle da expansão urbana. ${ }^{40}$

Como já evidenciado, o direito ao meio ambiente ecologicamente equilibrado é direito fundamental, portanto, de eficácia direta e imediata, o que não admite postergações. Em outras palavras, o Plano Diretor não pode ser concebido como um plano etéreo, meramente programático, uma carta de intenções que se apresente apenas para propaganda ou satisfação meramente formal de

\footnotetext{
39 Juarez Freitas, Sustentabilidade: direito ao futuro, Editora Fórum. Belo Horizonte, 2011, pp. $41-42$

${ }^{40}$ Maria Ilma Silva Dias, Gestão Urbana: entraves, desafios e avanços na implementação dos planos diretores: estudo de caso Barra do Piraí-RJ. Dissertação de mestrado em Urbanismo, Programa de Pós-Graduação em Urbanismo, Pontifícia Universidade Católica de Campinas, 2011 , p. 146.
} 
imperativos legais, mas deve ser o fruto de uma reflexão e de uma decisão política que se irmane com os demais instrumentos e mecanismos de governo, a fim de que se possa atingir o bem comum, que é o fim de toda a sociedade política". 41

Não obstante, é imperioso destacar que a conjuntura introduzida no ordenamento jurídico brasileiro com o Estatuto da Cidade rompeu a concepção tradicional que separa planejamento e gestão. ${ }^{42} \mathrm{O}$ modelo de Plano Diretor apresentado, parte do pressuposto de que a cidade é produzida por uma multiplicidade de agentes, sendo que o Plano deve coordenar essas ações, configurando-se como um "pacto", que atenda ao interesse coletivo. Dessa forma, o Plano assume o caráter de um processo político, por meio do qual o Poder Público canaliza esforços em objetivos prioritários definidos coletivamente como fundamentais para o desenvolvimento da cidade.

Nesse sentido, difere da concepção tradicional, que pratica uma separação total entre planejamento e gestão e dá espaço para a emergência de conflitos entre essas duas dimensões, operando o planejamento apenas na esfera técnica e a gestão na dimensão política. É necessário conjugar as duas visões, almejando atingir um fim que ultrapasse os interesses eleitoreiros. É necessário ter visão de futuro e o Plano Diretor aponta o futuro, o rumo a ser seguindo tendo como base o passado e o presente.

O processo de aprovação do plano não leva em consideração suas especificidades técnicas, o que permite que emendas o deformem, resultando em regras incoerentes e contraproducentes. Depois de aprovado o plano, qualquer lei pontual pode alterá-lo. Depois de algum tempo não se sabe sequer o que está ou não em vigor. A terminologia dos planos e leis urbanísticas é distinta em cada município. Cada um cria uma classificação de zonas próprias, cujo regime jurídico muitas vezes se confunde. A mera leitura de um mapa exige profundo conhecimento da legislação local. Há grande dificuldade em ter acesso

\footnotetext{
${ }^{41}$ Caramuru Afonso Francisco, Estatuto da Cidade Comentado, Juarez de Oliveira. São Paulo, 2001, p. 245.

${ }^{42} \mathrm{Na}$ visão anterior ao Estatuto da Cidade, o planejamento operaria apenas na dimensão técnica, enquanto que a gestão operaria na dimensão política. Brasil, Estatuto da Cidade: guia para implementação pelos municípios e cidadãos, Coordenação de Publicações. Brasília, Câmara dos Deputados, 2002, p. 40.
} 
as leis municipais e saber o que está ou não em vigor. A multiplicação de conceitos e normas a respeito do mesmo objeto cria um verdadeiro código próprio, que só pode ser lido por especialistas na legislação de cada município. ${ }^{43}$ Sob o ponto de vista da divisão de competências legislativas, a edição do Estatuto da Cidade previu diretrizes gerais para o desenvolvimento da política urbana e, para além disso, atualmente existem padrões legais, princípios, objetivos e diversos institutos que objetivam a realização de políticas de desenvolvimento urbano, em bases democráticas, bem como a concretização da função social da propriedade, consoante os objetivos e valores expressos no Estatuto.

Entretanto, apesar de existirem parâmetros gerais para que os Estadosmembros e municípios criem e adequem suas normas urbanísticas e o processo de planejamento urbano às diretrizes contidas no Estatuto da Cidade, não é possível inferir que existe uma harmonização legislativa sobre desenvolvimento urbano.

A falta de compatibilidade e inter-relação entre as políticas públicas, no Brasil é, de acordo com Daniella Maria dos Santos Dias, consequência da inexistência de parâmetros claros de atuação, o que gera políticas replicadas, incongruentes e muitas vezes incompatíveis. Para a autora, não existem pautas claras que definam as bases de ação para os entes políticos desenvolverem suas atribuições de forma cooperativa, pois não há a coordenação entre as atividades administrativas. ${ }^{44}$

Esta falta de coordenação ganha corpo com as disfunções decorrentes da incorreta compreensão da divisão de competência legislativa concorrente, cumulada com a profusão legislativa nos três níveis políticos. Em outras palavras, se a obrigatoriedade para a concretização de políticas públicas para os espaços urbanos é competência de todos os entes federativos, muitas vezes, a interpretação literal do capítulo da Constituição Federal brasileira destinado à política urbana leva à equivocada conclusão de que a responsabilidade para o

\footnotetext{
43 Victor Carvalho Pinto, Direito Urbanístico: plano diretor e direito de propriedade, Revista dos Tribunais. São Paulo, 2014, p. 39.

${ }^{44}$ Daniella Maria dos Santos Dias, Planejamento e Desenvolvimento Urbano no Sistema Jurídico Brasileiro..., cit., p. 152.
} 
cumprimento das normas constitucionais e do Estatuto da Cidade é responsabilidade restrita do Poder Público municipal. ${ }^{45}$

O Plano é incumbido também da tarefa de transformar em normas as metas e diretrizes da política urbana, garantindo o pleno desenvolvimento das funções sociais da cidade e o cumprimento da função social da propriedade. Ele deverá explicitar um projeto de cidade, resultante das opções conscientes e negociadas entre todos os agentes produtores da cidade, envolvidos de forma democrática e participativa no processo de elaboração do plano. Diante deste cenário, é inegável a parcela de responsabilidade do município no desenvolvimento das atividades e obrigações para a consecução do direito à cidade e 0 desenvolvimento das funções sociais da cidade para todos os seus habitantes. No entanto, essa tarefa não é exclusiva do município.

Embora os entes municipais possuam, formalmente, autonomia política, administrativa e financeiro-tributária, tal autonomia é, na prática, inexistente, pois não conseguem obter recursos suficientes para o cumprimento de ampla gama de atribuições e competências administrativas que lhes foram delegadas pelo texto constitucional. Em outros termos, a descentralização de serviços para o cumprimento dos interesses locais resta prejudicada, pois a restrição da autonomia financeira dos municípios compromete qualquer eventual intervenção do poder político municipal sobre a ordem econômica e restringe as possibilidades de implementação de políticas urbanísticas. ${ }^{46}$

O Plano Diretor deve, portanto, ser assumido obrigatoriamente como um processo político, por meio do qual o Poder Público, por meio de um esforço integrado entre União, Estados e Municípios, canaliza seus esforços, capacidade técnica e potencialidades locais em torno de alguns objetivos prioritários. Dessa forma, procura-se evitar a dissipação de forças em intervenções fragmentadas, em prol de um foco nos pontos vistos como fundamentais para o conjunto da cidade, a proteção do espaço físico, mas, sobretudo, a proteção dos bens e

\footnotetext{
${ }^{45}$ Daniella Maria dos Santos Dias, Planejamento e Desenvolvimento Urbano no Sistema Jurídico Brasileiro..., cit., p. 152.

${ }^{46}$ Daniella Maria dos Santos Dias, Planejamento e Desenvolvimento Urbano no Sistema Jurídico Brasileiro..., cit., p. 153.
} 
direitos metaindividuais, heterogêneos, evidência de valores de cidadania na arte do cuidado com o meio ambiente. ${ }^{47}$

\section{MECANISMOS PARA A EFETIVAÇÃO DO PLANO DIRETOR}

Não há como negar o grande avanço que representou o Estatuto da Cidade para o planejamento dos municípios, conferindo um crescimento ordenado de modo a assegurar o princípio do meio ambiente ecologicamente equilibrado. De mesmo modo, não se pode olvidar que a execução plena e efetiva destes instrumentos legais ainda encontra diversos obstáculos, conforme apontado anteriormente.

Torna-se crucial, portanto, a elaboração de mecanismos que visem melhorar a eficácia dos planos diretores municipais, principalmente no que atine à sua execução, aprimorando e destacando os avanços já trilhados e, ao mesmo tempo, superando os entraves que se impõem.

Um dos principais gargalos que se apresenta é a ausência de um diálogo efetivo entre o plano diretor e os instrumentos legais orçamentários (Plano Plurianual, Lei de Diretrizes Orçamentárias e Lei Orçamentária Anual).

É patente que o Estatuto da Cidade prevê, no artigo 40, $\S 1^{\circ}$, que o plano plurianual, as diretrizes orçamentárias e o orçamento anual devem incorporar as diretrizes e as prioridades contidas no plano diretor. Todavia, de modo efetivo, a relação lógica entre leis orçamentárias e o plano diretor ainda é incipiente. Não raro são formuladas alterações nas leis orçamentárias em decorrência da falta de recursos, principalmente quando há diminuição na arrecadação da receita em relação ao previsto para o exercício financeiro. Os Planos Diretores atravessam várias gestões, porém, mesmo quando legalmente instituídos, são preteridos aos planos de governo, que acabam ganhando destaque. O Plano Plurianual e o orçamento anual, por possuírem uma temporalidade mais próxima ao mandato,

\footnotetext{
47 José Francisco de Matos e Silva, "O Estatuto da Cidade e o Plano Diretor: uma necessidade ambiental", en Revista da Procuradoria-Geral do Município de Juiz de Fora - RPGMJF 3 (jan./dez. 2013). Disponível em: <http://www.bidforum.com.br/PDI0006.aspx?pdiCntd=99947>. Acesso em: 04 dez. 2018.
} 
acabam sendo os instrumentos utilizados pelos gestores para executarem seus Planos de Governo.

A forma como se apresenta um plano diretor e, principalmente, como ele se garante como instrumento eficaz da implementação e da manutenção de qualidade de vida da cidade e da sua política local de desenvolvimento são essenciais para a sua efetividade. Para a autora, se tal instrumento não for claramente explicitado, corre-se o risco de cair no domínio de uma prática sem regras e sem limites, no predomínio do empirismo e da aleatoriedade. Por isso, a elaboração e o processo de implementação têm que estar garantidos simultaneamente, com procedimentos metodológicos e técnicos através de um processo político real. ${ }^{48}$

É essencial, portanto, aproximar o planejamento da gestão, para que os Planos Diretores ultrapassem o estado de mero documento de boas intenções e cheguem a constituir um verdadeiro instrumento orientador do investimento público e da gestão orçamentária no que concerne o desenvolvimento urbano. ${ }^{49}$ Daí a necessidade de implementação do plano diretor articulada com o ciclo orçamentário, para além do cumprimento das formalidades legais. Defende-se, neste ínterim, que a previsão de ações de ordenação urbana no orçamento municipal não seja apenas em abstrato, mas pautada em ações coordenadas e concretas que permitam a sua efetiva implementação.

Ainda no tocante às questões orçamentárias e financeiras, é importante destacar que, para o devido cumprimento de suas competências constitucionais, o município precisa ter recursos financeiros suficientes para cumprir a diversidade de atividades, responsabilidades e serviços para que os espaços urbanos e rurais sejam locais propícios para o desenvolvimento humano. Significa dizer que a existência de marco regulatório inovador - expresso no texto constitucional, no Estatuto da Cidade e nas demais normas urbanísticas especiais - deve ser acompanhada de efetivas possibilidades de o Poder Público atuar, de forma eficiente, para transformar a realidade urbana. Contudo, a necessária atuação do Poder Público municipal, no plano da realidade, depende

${ }^{48}$ Suely Franco Netto Gonzalez, O Plano Urbano no Processo de Planejamento, IPDF, GDF. Brasília, 1995, p. 3.

${ }^{49}$ Ermínia Maricato, Brasil, cidades: alternativas para a crise urbana, Vozes. Petrópolis, 2011, pp. 117. 
de capacidade financeira, da existência de recursos financeiros para prover os serviços e obras necessários ao planejamento, ao desenvolvimento urbano, com segurança, qualidade e proteção ao meio ambiente.

A efetividade de normas de ordem pública e de interesse social para a consecução das políticas de desenvolvimento urbano depende de planejamento coordenado e de políticas de desenvolvimento urbano que consigam integrar as ações dos entes federativos. Porém, a efetiva melhoria dos assentamentos humanos, por meio de políticas integradas que venham propiciar espaços urbanos dignos para a educação, para o trabalho, para o lazer, para o acesso à moradia em condições dignas, só se tornará realidade, se os entes da Federação tiverem efetiva autonomia financeira para intervir, na ordem econômica e na ordem urbana. Significa dizer que a verdadeira possibilidade fática para os poderes da Federação intervirem na ordem econômica, de forma a regular as atividades privadas, em razão dos interesses coletivos e sociais, depende da existência de receitas para 0 desenvolvimento de suas respectivas competências e funções. ${ }^{50}$

Sabe-se que, apesar de a Constituição Federal de 1988 ter ampliado os percentuais de transferências tributárias aos Estados e municípios, referidas transferências são insuficientes para que cumpram com suas responsabilidades, pois a distribuição dos recursos fiscais pelo governo central aos demais entes federativos não revela um verdadeiro equilíbrio entre os encargos e as despesas deles decorrentes. ${ }^{51}$

Nesse sentido, é preciso superar o critério legal, puramente formal, utilizado para subsidiar a produção de políticas públicas como forma de estabelecer os limites entre os espaços urbanos e rurais. As políticas públicas, para o desenvolvimento territorial do Brasil, devem ultrapassar a visão simplista e restrita que considera a definição dos espaços urbanos e rurais unicamente por meio de padrão normativo, que desconsidera as atividades econômicas neles desenvolvidas bem como as técnicas empregadas e os modos de vida.

\footnotetext{
${ }^{50}$ Daniella Maria dos Santos Dias, Planejamento e Desenvolvimento Urbano no Sistema Jurídico Brasileiro, Juruá Editora. Curitiba, 2012, p. 152.

${ }^{51}$ Daniella Maria dos Santos Dias, Planejamento e Desenvolvimento Urbano no Sistema Jurídico Brasileiro, Juruá Editora. Curitiba, 2012, p. 153.
} 
Outro aspecto legislativo que merece correções é a questão do detalhamento do plano diretor. A observação se determinado item fixado no projeto foi ou não realizado comprova a efetividade do plano e a sua correta execução.

A respeito do detalhamento do plano diretor, alguns doutrinadores, a exemplo de José Afonso da Silva, aconselha não ser o plano muito minucioso, pois a atuação concreta deveria ser relegada aos planos executivos. ${ }^{52}$ Contudo, essa teoria não se mostra a mais acertada, sobretudo a partir dos problemas ocorridos em plano diretores genéricos. O mais adequado é a construção de um Plano Diretor detalhado, a fim de que seus executores tenham real noção do que se quer alcançar com a implantação de suas metas.

O plano genérico perde-se no tempo e, via de regra, não é executado. Isso sem contar que a omissão das autoridades não pode ser levada em consideração, em vista do alto grau de abstração do instrumento diretor, que deveria ser cartilha minuciosa das ações de autoridades governamentais. ${ }^{53}$

Consoante destaca Cláudio Bernardes, o detalhamento do plano diretor é importante para a implementação das políticas de desenvolvimento urbano nas cidades, pois permite entender de maneira correta os dispositivos e objetivos inseridos na lei e formatar adequadamente os instrumentos passíveis de implantação em seus municípios. ${ }^{54}$

É possível apontar, de igual modo, medidas que podem favorecer o controle e acompanhamento da execução do Plano Diretor por meio da participação popular. O próprio Estatuto da Cidade já prevê, como diretriz geral da política urbana, a gestão democrática por meio da participação da população e de associações representativas dos vários segmentos da comunidade na formulação, execução e acompanhamento de planos, programas e projetos de desenvolvimento urbano. Especificamente, o artigo 40, $4^{\circ}$ dispõe que, no processo de elaboração do plano diretor e na fiscalização de sua implementação, deve ser garantida a promoção de audiências públicas e debates com a

52 Edson Ricardo Saleme; Solange Teles Silva, Plano diretor, participação popular e responsabilidades, Disponível em: <http://w.conpedi.org/manaus/arquivos/anais/bh/edson_ ricardo_saleme.pdf>. Acesso em: 14 jul. 2009], p. 1518.

${ }^{53}$ Saleme, Silva, Plano diretor, participação popular..., cit.

${ }^{54}$ Cláudio Bernardes, Plano diretor estratégico, lei de zoneamento e atividade imobiliária em São Paulo, O Nome da Rosa. São Paulo, 2005, p. 17. 
participação da população e de associações representativas dos vários segmentos da comunidade.

A audiência pública, quando realizada de modo adequado, configura um instrumento hábil a garantir que a atuação estatal seja orientada, da melhor forma possível no atendimento dos anseios sociais, direcionando a elaboração e a implantação de políticas públicas condizentes com a realidade urbana. $\mathrm{Na}$ concepção de Mariana Mencio, com o intuito de mitigar a segregação social de alguns grupos da sociedade civil, a audiência pública permite, de um lado, que o administrado manifeste sua opinião com vistas à melhor decisão do Poder Público. Sob outro viés, a audiência pública permite o debate público, ocasião em que o administrado pode confrontar seus pontos de vista, tendências, opiniões, razões e opções com os de outros administrados e com os do próprio Poder Público, com o intuito de contribuir para a melhor decisão administrativa. ${ }^{55}$ Deve ser destacado que a atuação do Poder Público, através da gestão do espaço urbano, deve, de fato, ser capaz de garantir aos indivíduos os direitos fundamentais expressamente preconizados pela Constituição Federal, notadamente no que diz respeito ao direito à moradia, à educação, à segurança, ao lazer, à saúde, ao trabalho, entre outros. Nesse sentido, a gestão compartilhada do meio ambiente urbano implica na elaboração de políticas públicas condizentes com a realidade e os anseios sociais, assegurando aos indivíduos a possibilidade de participar da construção de uma cidade sustentável. É justamente com base neste pressuposto que a gestão democrática das cidades deve ser considerada uma decisão coletiva, efetiva e compartilhada entre a administração pública e a sociedade, resultando em um pacto social, em que os vários interesses envolvidos sejam ponderados de maneira a ordenar o território de forma sustentável, assegurando basicamente à população espaços adequados ao lazer, transporte, habitação e trabalho, para além das questões inerentes ao meio ambiente natural. ${ }^{56}$

\footnotetext{
${ }^{55}$ Mariana Mencio, "As consequências jurídicas advindas da falta de participação popular durante o processo de elaboração e aprovação do plano diretor", en Revista MPMG Jurídico, ano I, n. 4. Belo Horizonte, 2006, p. 112.

${ }^{56}$ Mariana Mencio, "As consequências jurídicas advindas da falta de participação popular durante o processo de elaboração e aprovação do plano diretor"... cit., p. 98.
} 
É oportuno destacar que a audiência pública, conforme previsto no Estatuto da Cidade, não vincula os órgãos públicos no tocante à manifestação dos indivíduos. Contudo, ela deve ser utilizada para orientar a atuação do gestor público municipal no planejamento das políticas urbanas, de modo a implantar políticas públicas condizentes com a realidade social. Tal perspectiva coloca impedimentos à Administração Pública, quando da elaboração do plano diretor, de adotar os denominados planos prontos, que acabam sendo elaborados de forma completamente desvinculada da realidade urbana local.

A ampliação da participação popular pode, ainda, evitar a edição de Planos Diretores mal elaborados tecnicamente ou propositalmente utilizados como ferramenta para favorecer determinados setores e grupos de influência. Neste sentido, as etapas indicadas para elaboração do Plano Diretor, consistentes nos estudos preliminares, diagnóstico, plano de diretrizes e instrumentação do plano deverão contar com a aplicação de alguns instrumentos de participação popular.

Trata-se, portanto, de fortalecer esses mecanismos legais, imprimindo maior transparência e criando as estruturas necessárias para a participação popular no plano diretor desde as discussões iniciais até a execução. A participação da população perfaz, também, a criação de órgãos de monitoramento da aplicação do plano diretor e a previsão de dispositivos no próprio instrumento legal que visem a garantir que na mudança de governo, a política de desenvolvimento urbano do plano diretor não se torne obsoleta como diretriz para o Poder Executivo.

Resta claro, também, que a elaboração do plano diretor deve ser realizada pelo próprio Poder Público municipal, restringindo-se a contratação de assessoria externa somente aos casos que envolvam assuntos técnicos específicos. Somente assim, o plano diretor atenderá às necessidades e peculiaridades do Município, garantindo uma viabilidade técnica e política. ${ }^{57}$

As realizações e a própria importância do Plano Diretor Municipal só podem ser mensuradas se forem previstas formas de monitoramento e controle que abordem aspectos de eficiência, eficácia e efetividade das ações e respectivos investimentos empreendidos, com base em ferramentas que possibilitem a

\footnotetext{
${ }^{57}$ Priscila Ferreira Blanc, Plano Diretor Urbano e Função Social da Propriedade, cit., p. 167.
} 
apropriação por parte da população. A avaliação deve ser entendida como parte do processo do desenvolvimento das políticas públicas, mais especificamente das políticas urbanas em direta relação com o Plano Diretor, exigindo uma averiguação sistemática do cumprimento de sua função social. ${ }^{58}$

\section{CONSIDERAÇÕES FINAIS}

O tema tratado no presente estudo é amplo e vastíssimo, permitindo diversas considerações. Foram apontados alguns aspectos mais relevantes que, sem a pretensão de esgotar a discussão, podem contribuir para a efetivo aprimoramento dos planos diretores.

A tratativa do tema ao longo do trabalho, tendo como enfoque o problema de pesquisa, buscou perseguir quais são as principais causas da ausência de efetividade na implementação dos planos diretores no Brasil, e quais mecanismos poderiam ser utilizados para possibilitar maior eficácia no seu processo de elaboração e execução. Nesta perspectiva, é possível pontuar algumas premissas que podem contribuir para o desenvolvimento da temática.

De início, é inegável que o Estatuto da Cidade, ao prever a obrigatoriedade de formulação de Plano Diretor, representou uma mudança significativa na ordenação urbana e, consequentemente, na concretização do direito à sadia qualidade de vida. A despeito de a exigência não se estender à totalidade dos municípios, houve um avanço significativo nas políticas ambientais e urbanísticas de modo geral. Para além da obrigatoriedade de elaboração, o Estatuto da Cidade vislumbrou o Plano Diretor como um processo político, por meio do qual o Poder Público canaliza seus esforços, capacidade técnica e potencialidades locais em torno de alguns objetivos prioritários.

Todavia, em resposta ao problema de pesquisa, evidencia-se que há alguns fatores que dificultam a efetividade na execução do Plano Diretor e, consequentemente, da garantia do direito ao meio ambiente ecologicamente equilibrado. Entre eles, se destacam: (i) a falta de planejamento e de

\footnotetext{
${ }^{58}$ Amanda Munhoz Buba, "Construindo a relação entre planejamento orçamentário e Plano Diretor", en "Revista do Ministério Público de Contas do Estado do Paraná - MPC" v. 6 n. 11 (2019): novembro/maio, p. 35.
} 
detalhamento das medidas previstas no plano diretor; (ii) a alegada falta de recursos financeiros decorrentes do decréscimo na arrecadação; (iii) a ausência de previsão orçamentária das medidas contidas no Plano Diretor; (iv) a necessidade de atendimento, pelo Poder Público, de outras necessidades tidas como essenciais, e; (v) o infundado argumento de que o plano diretor é dotado de caráter meramente programático, ou seja, de que trataria apenas de programas e diretrizes para atuação futura dos órgãos estatais.

Tais alegações não encontram embasamento legal diante do cenário jurídico atual, principalmente em relação à ordem constitucional. Primeiro porque as leis orçamentárias devem estar pautadas em critérios concretos para fixação de receita e despesa, só admitindo restrições em situações excepcionais. Segundo porque a execução do plano diretor é instrumento para a implementação do direito fundamental ao meio ambiente ecologicamente equilibrado, e que, como tal, tem eficácia direta e imediata. Terceiro, porque a essencialidade da implantação do plano diretor reside no fato de que, pela sua execução, atendese a um sem-número de outros direitos: saúde, educação, saneamento básico, transporte e mobilidade, acessibilidade, moradia digna, entre outros.

Nesta perspectiva, como forma de contribuir para o aprimoramento da execução dos planos diretores, foram apontados alguns mecanismos aptos a corrigir deficiências em relação à execução do plano diretor: (i) a implementação do plano diretor articulada com o ciclo orçamentário, para além do cumprimento das formalidades legais; (ii) o detalhamento do plano diretor, de modo a otimizar o acompanhamento de sua execução; (iii) a criação de estruturas que permitam a participação popular no plano diretor desde as discussões iniciais até a execução; (iv) a implantação de órgãos de monitoramento da aplicação do plano diretor e a previsão de dispositivos no próprio instrumento legal que visem a garantir que na mudança de governo, a política de desenvolvimento urbano do plano diretor não se torne obsoleta, e (v) a mudança de perspectiva, para que a elaboração do plano diretor seja vista como norma de execução imediata, da qual confluem a concretização de outros direitos fundamentais.

Embora, à primeira vista, soem singelas, as medidas apontadas podem contribuir decisivamente para melhorar o processo de planejamento urbano, conferindo maior eficácia ao instrumental do plano diretor em busca de cidades 
sustentáveis, com o pleno e efetivo atendimento ao direito ao meio ecologicamente equilibrado.

$E$ nem se pense que tais medidas não seriam úteis, porque não mencionam explicitamente intervenções nas questões ambientais. Elas podem ser de grande utilidade, porque indiretamente poderão ser decisivas na implantação de um direito humano ao meio ambiente ecologicamente equilibrado. Por exemplo, o plano diretor poderá indicar a necessidade de criação e conservação de novas áreas verdes, e um orçamento bem programado será a via para a efetiva implementação.

$E$, ainda que se possa cogitar que o pleno e efetivo atendimento ao direito ao meio ecologicamente equilibrado possa parecer utopia, recordemos Eduardo Galeano, que comparava as utopias ao horizonte: se eu avanço um passo, o horizonte recua um passo; se eu avanço dois passos, o horizonte recua dois passos: eu avanço cem metros, o horizonte recua cem metros; eu subo a colina, e o horizonte se esconde atrás da colina seguinte. Mas então, perguntava ele, para que servem as utopias? Servem para isso, para nos fazer caminhar!

\section{BIBLIOGRAFIA}

ANTUNES, Paulo de Bessa. Direito ambiental. Rio de Janeiro, Lumen Juris, 2004.

BERCOVICI, Gilberto. Desigualdades regionais, estado e constituição. São Paulo, Max Limonad, 2003.

BERNARDES, Cláudio. Plano diretor estratégico, lei de zoneamento e atividade imobiliária em São Paulo. São Paulo, O Nome da Rosa, 2005.

BLANC, Priscila Ferreira, Plano Diretor Urbano e Função Social da Propriedade. Curitiba, Juruá Editora, 2004.

BRASIL. Estatuto da Cidade: guia para implementação pelos municípios e cidadãos. Brasília, Câmara dos Deputados, Coordenação de Publicações, 2002. BUBA, Amanda Munhoz. "Construindo a relação entre planejamento orçamentário e Plano Diretor", em Revista do Ministério Público de Contas do Estado do Paraná - MPC, v. 6., n. 11, novembro/maio, 2019. 
DIAS, Daniella Maria dos Santos. Planejamento e Desenvolvimento Urbano no Sistema Jurídico Brasileiro, Juruá Editora. Curitiba, 2012.

DIAS, Maria Ilma Silva. Gestão Urbana: entraves, desafios e avanços na implementação dos planos diretores: estudo de caso Barra do Piraí-RJ (Dissertação de mestrado em Urbanismo, Programa de Pós-Graduação em Urbanismo, Pontifícia Universidade Católica de Campinas, 2011).

FENSTERSEIFER, Tiago. Direitos fundamentais e proteção ambiental: $A$ dimensão ecológica da dignidade humana no marco jurídico-constitucional do Estado Socioambiental de Direito. Porto Alegre, Livraria do Advogado Editora, 2008.

FRANCISCO, Caramuru Afonso. Estatuto da Cidade Comentado. São Paulo, Juarez de Oliveira, 2001.

FREITAS, José Carlos de. "Estatuto da cidade e improbidade administrativa", en Temas de direito urbanístico, Ministério Público do Estado de São Paulo, Imprensa Oficial do Estado. São Paulo, 2005.

FREITAS, Juarez. Sustentabilidade: direito ao futuro. Belo Horizonte, Fórum, 2011.

FREITAS, Vladimir Passos de. A Constituição Federal e a efetividade das normas ambientais. São Paulo, Revista dos Tribunais, 2005.

GABARDO, Emerson. Interesse público e subsidiariedade: a sociedade civil para além do bem e do mal. Belo Horizonte, Fórum, 2009.

GASPARINI, Diógenes. "Aspectos Jurídicos do Plano Diretor", en Interesse Público - IP 31 (ano 7, maio / jun. 2005). Disponível em: <http://www.bidforum.com.br/PDI0006.aspx?pdiCntd=49975>. [Último acesso em: 12/12/2020].

GONZALEZ, Suely Franco Netto, O Plano Urbano no Processo de Planejamento, IPDF, GDF. Brasília, 1995.

GRANZIERA, Maria Luiza Machado. Direito Ambiental. São Paulo, Atlas, 2011. GERAQUE, Eduardo. Tirar o Plano Diretor do papel será o maior desafio após a aprovação, in Folha de São Paulo (29/06/2014). Disponível em: 
https://www1.folha.uol.com.br/cotidiano /2014/06/1478137-tirar-o-plano-diretordo-papel-sera-o-maior-desafio-apos-a-aprovacao.shtml. [Último acesso em 10/12/2018].

JARDIM, Zélia Leocádia da Trindade, "Regulamentação da política urbana e garantia do direito à cidade", en Direito da Cidade: novas concepções sobre as relações jurídicas no espaço social urbano, Lumen Juris. Rio de Janeiro, 2007.

KOHLSDORF, Maria Elaine; FARRET, Ricardo Libanês; GONZALEZ, Suely Franco Netto; HOLANDA, Frederico Rosa Borges de. O Espaço da cidade: contribuição à análise urbana, Projeto Editores Associados. São Paulo, 1985.

MACHADO, Paulo Affonso Leme. Direito Ambiental Brasileiro. São Paulo, Malheiros, 2016.

MAGALHÃES, Marco Túlio Reis. "Desafios de concretização do direito (fundamental) ao meio ambiente ecologicamente equilibrado: o exemplo da concessão de florestas e do aquecimento global", en Revista Fórum de Direito Urbano e Ambiental - FDUA 47 (set./out. 2009). Disponível em: <http://www.bidforum.com.br/PDI0006.aspx?pdiCntd=63151>. [Último acesso em: 15/12/2018].

MARICATO, Ermínia, Brasil, cidades: alternativas para a crise urbana, Vozes. Petrópolis, 2011.

MATTOS, Liana Portilho. A efetividade da função social da propriedade urbana, Temas \& Ideias. Rio de Janeiro, 2003.

MEIRELLES, Hely Lopes. Direito de Construir. Malheiros, São Paulo, 2011.

MENCIO, Mariana Mencio. "As consequências jurídicas advindas da falta de participação popular durante o processo de elaboração e aprovação do plano diretor", en Revista MPMG Jurídico, ano I, n. 4. Belo Horizonte, 2006.

MESQUITA, Amanda Pires; FERREIRA, William Rodrigues. "O Município e o planejamento rural: o plano diretor municipal como instrumento de ordenamento das áreas rurais", en Espaço em Revista 18 (n. 1, jan/jun. 2016).

MILARÉ, Édis. Direito do ambiente. São Paulo, Revista dos Tribunais, 2013. 
MUKAI, Toshio. "Planejamento municipal: o plano diretor e o Estatuto da Cidade", en Fórum de Direito Urbano e Ambiental 1 (jan./fev. 2002). Disponível em: <http://www.bidforum.com.br/PDI0006.aspx?pdiCntd=10018>. [Último acesso em: 13/11/2018].

PINTO, Victor Carvalho. Direito Urbanístico: plano diretor e direito de propriedade. Revista dos Tribunais, São Paulo, 2014.

RISTER, Carla Abrantkoski. Direito ao desenvolvimento: antecedentes, significados e consequências. Rio de Janeiro, Renovar, 2007.

RODRIGUES, José Eduardo Ramos; FERNANDES, Valdir; PHIPIPPI JÚNIOR, Arlindo. "Política e gestão ambiental no Brasil", en GALLI, Alessandra (coord.), Direito Socioambiental. Homenagem a Vladimir Passos de Freitas. Curitiba, Juruá Editora, 2010.

SALEME, Edson Ricardo; SILVA, Solange Teles. Plano diretor, participação popular e responsabilidades. Disponível em: <http://w.conpedi.org/manaus/arquivos/anais/bh/edson_ ricardo_saleme.pdf $>$. Acesso em: 14/06/2019.

SANTIN, Janaína Rigo; LEIDENS, Letícia Virgínia. "Plano Diretor: instrumento de efetivação da função social da propriedade urbana e participação popular", en Revista Brasileira de Direito Municipal - RBDM 20 (abr./ jun. 2006). Disponível em: <http://www.bidforum.com.br/PDI0006.aspx?pdiCntd=35993>. [Último acesso em: 13/11/2018].

SAULE JÚNIOR, Nelson. Direito à cidade: trilhas legais para o direito às cidades sustentáveis. São Paulo, Max Limonad, 1999.

SILVA, José Afonso da. Direito urbanístico brasileiro. São Paulo, Malheiros, 2006.

SILVA, José Afonso da. Direito ambiental constitucional. São Paulo, Malheiros, 2004.

SILVA, José Francisco de Matos e. "O Estatuto da Cidade e o Plano Diretor: uma necessidade ambiental", en Revista da Procuradoria-Geral do Município de Juiz de Fora - RPGMJF 3 (jan./dez. 2013). Disponível em: 
<http://www.bidforum.com.br/PDI0006.aspx?pdiCntd=99947>. [Último acesso em: 04/12/2018].

TRENNEPOHL, Terence Dornelles. Fundamentos de direito ambiental. Salvador, JusPodivm, 2007.

VENÂNCIO, Patrícia Gabai Venâncio. O Direito à Moradia Digna: um novo paradigma de atuação do Ministério Público à luz da gestão democrática da cidade, Dissertação de Mestrado em Direito da Cidade, Universidade do Estado do Rio de Janeiro. Rio de Janeiro, 2009. 